\title{
Kajian Potensi Kualitas Kayu Melalui Uji Marka Anatomi Pada Tanaman Puspa (Schima wallichii (DC.) Korth. Sebagai Tanaman Revegetasi Lahan Pascatambang
}

\author{
AHMAD TAUFIQ ${ }^{1}$ DAN ALPONSIN ${ }^{1}$ \\ ${ }^{1}$ Laboratorium Struktur dan Perkembangan Tumbuhan, Jurusan Biologi Fakultas Matematika dan \\ Ilmu Pengetahuan Alam, Universitas Andalas, Padang. \\ Jl. Limau Manis, Pauh, Kota Padang, Sumatera Barat. 25163 \\ Email: ahmadtaufiq@fmipa.unand.ac.id
}

Received 24 December 2017; Received in revised form 30 January 2018;

Accepted 8 February 2018; Available online 28 February 2018

\begin{abstract}
Revegetation is one of the way to remedy polluted area. Some plants have been applied as revegetation plant due to it has the fast-growing rate and adaptive to the critical area. Plant species which potential for revegetation has ability to live and survive and some are pioneer species. Puspa tree (Schima wallichii (D.C.) Korth.) is a pioneer species that commonly found at either primary or secondary forest and even at savana area. Puspa can be used as revegetation plant also because it is easy propagated and belonging to a semi-fire proof plant species. Therefore, ecologically, puspa suit to be used as revegetation plant species candidate for the land after mining. Besides of matching with environment, that plant should also meet with the economic use. Anatomical study had been conducted to ensure the wood use precisely based on its quality. Three samples from different locations revealed no significant differentiation by their anatomy characters. The result of observation showed the Puspa wood had a small $(50-100 \pi \mathrm{m})$ to very small $(<50 \pi \mathrm{m})$ pore with soliter shape and "baur" type. The Parenchyma type of Puspa wood is apotrakeal baur and medullary ray is classified to uniseriate and multiseriate, very tall and wide. This tissue comprised with two types off cell, procumbent and upright ray cell (heterocellular). The fibre had was long $(>1600 \mu \mathrm{m})$ with thick wall and tight lumen. The result of anatomical comparison study between Puspa's wood with commercial wood showed Puspa belonged to hardwood group grade 1 and 2 . These data should be used as a considerable report for a recommendation reference of using puspa as a plant species for the reclamation of after mining area and anyway provides economic benefit.
\end{abstract}

Keywords: apotrakeal, ecologically, pioneer, puspa, revegetation

\section{INTISARI}

Revegetasi merupakan salah satu upaya untuk memulihkan lingkungan tercemar. Beberapa tanaman telah dijadikan sebagai tanaman revegetasi karena termasuk kepada jenis cepat tumbuh (Fast Growing Species) dan adaptif pada lahan kritis. Jenis tumbuhan yang berpotensi untuk revegetasi lahan adalah jenis pohon yang dapat hidup pada lahan terbuka dan sebagian merupakan jenis tumbuhan pionir. Puspa (Schima wallichii (D.C.) Korth.) merupakan salah satu tumbuhan pionir yang umum dijumpai di hutan primer dan sekunder ataupun wilayah terganggu, bahkan juga di padang ilalang. Puspa dapat dijadikan sebagai tanaman revegetasi karena relatif tidak sulit untuk dikembangkan di lapangan dan termasuk salah satu tanaman yang resisten terhadap kebakaran. Dengan demikian, secara ekologis tumbuhan Puspa sangat cocok digunakan sebagai kandidat tanaman revegetasi lahan bekas tambang. Di samping kesesuaian secara ekologis, perlu juga diutamakan tumbuhan tersebut bermanfaat secara ekonomi. Studi anatomi terhadap jenis ini telah dilakukan untuk memastikan peruntukan kayunya sesuai dengan kriteria kualitas kayu. Penelitian yang dilakukan di ke-3 lokasi tidak memperlihatkan perbedaan yang nyata jika diamati berdasarkan karakter anatomi. Berdasarkan karakter anatomi, tumbuhan Puspa (S. wallichii) menunjukkan profil 
bahwa tumbuhan ini mempuyai pori dengan kategori kecil $(50-100 \pi \mathrm{m})$ dan sangat kecil $(<50 \pi \mathrm{m})$ dengan tipe soliter dan pola sebaran yaitu baur. Tipe parenkim adalah apotrakeal baur. Jari-jari empulur berbentuk uniseriate-multiseriate, tingginya tergolong kedalam kategori sangat tinggi, sedangkan lebarnya tergolong kedalam kategori lebar. Komposisi jari-jari empulur adalah bertipe heteroseluler yaitu dengan susunan sel baring/ procumbent ray cell dan sel tegak/upright ray cell. Serat termasuk kedalam kategori panjang $(>1600 \mu \mathrm{m})$, dinding serat tebal dan lumen sempit. Penentuan kualitas kayu dilakukan dengan membandingkan karakter anatomi kayu yang diteliti dengan kayu industri yang sudah pernah dilaporkan dan menunjukkan bahwa tumbuhan puspa ( $S$. wallichii) masuk kedalam kelompok kayu kuat kelas I-II. Data penelitian ini tentu dapat digunakan sebagai bahan acuan rekomendasi penggunaan tumbuhan jenis puspa sebagai kandidat tanaman reklamasi yang bermanfaat secara ekonomi di lahan pascatambang.

Kata kunci: apotrakeal, ekologi, pionir, puspa, revegetasi

\section{PENDAHULUAN}

Saat ini Indonesia merupakan salah satu negara di dunia yang mengalami krisis lingkungan serius. Penggundulan hutan terus meningkat untuk perluasan industri pertambangan, industri perkebunan, pemukiman dan berbagai kegiatan antropogenik lainnya. Kegiatan pembangunan dan penambangan selama ini kurang diikuti dengan penanganan dampaknya terhadap lingkungan. Kegiatan antropogenik yang sering menjadi sorotan adalah di sektor pertambangan. Jika kegiatan ini tidak diimbangi dengan penanganan yang tepat dapat menyebabkan kerusakan lingkungan dan membahayakan kelangsungan hidup manusia. Akibat yang ditimbulkan kegiatan pertambangan antara lain tidak adanya horisonisasi tanah, terjadinya pemadatan, berkurangnya unsur hara esensial, adanya pencemaran oleh logam dan turunnya populasi mikroba tanah (Rahmawaty, 2000 dalam Afifah, 2014). Pada umumnya tanah bekas penambangan telah kehilangan lapisan tanah bagian atas yang subur (top soil) dan digantikan oleh lapisan bawah yang kurang subur dan miskin hara.

Sebagai upaya untuk pemulihan kondisi hutan beserta ekosistem yang sudah terganggu tersebut pemerintah mencanangkan program yang dikenal dengan upaya Restorasi Ekosistem di wilayah hutan produksi yang diatur lewat Izin Usaha Pemanfaatan Hasil Hutan Kayu Restorasi Ekosistem (IUPHHKRE). Jika hutan konservasi dikelola oleh pemerintah, maka Restorasi Ekosistem (RE) dilakukan oleh swasta/masyarakat yang berminat melalui sistem perizinan IUPHHKRE. Kegiatan IUPHHK-RE bertujuan untuk mengembalikan unsur hayati (flora dan fauna) serta non-hayati (tanah, iklim dan topografi) pada suatu kawasan kepada jenis asli, sehingga tercapai keseimbangan hayati dan ekosistemnya (Menteri Kehutanan Republik Indonesia, 2008). Demikian pula, RE merupakan upaya untuk mempertahankan fungsi dan keterwakilan ekosistem hutan alam melalui kegiatan pemeliharaan, perlindungan dan pemulihan ekosistem hutan.

Langkah awal yang perlu dilakukan terhadap Restorasi Ekosistem lahan kritis bekas tambang adalah menyuburkan kembali dengan cara penanaman kembali/revegetasi. Pada tahap ini tanaman berperan sebagai bioakumulator, dengan cara menyerap dan mengonversi logam berat yang ada pada tanah kawasan bekas penambangan (Ashraf et al., 2011). Pada revegetasi, penggunaan tanaman pangan harus dihindari, karena logam berat yang terakumulasi beresiko termakan dan berpindah ke tubuh manusia. Oleh karena itu pemilihan tanaman revegetasi yang tepat penting dilakukan. Jenis tumbuhan yang berpotensi untuk revegetasi lahan adalah jenisjenis pohon yang dapat hidup pada lahan terbuka dan sebagian merupakan jenis-jenis pionir. Tumbuhan berkayu yang termasuk ke dalam kelompok FGS (Fast Growing Species) dapat tumbuh dengan baik di tempat tandus dan kritis sehingga dapat menjadi tanaman pilihan dalam upaya revegetasi di lahan bekas tambang. 
Tanaman Puspa (Schima wallichii (D.C.)) Korth. merupakan salah satu tumbuhan berkayu dengan habitus pohon yang menjadi pionir dan umumnya dijumpai di hutan primer dan sekunder ataupun wilayah terganggu, bahkan juga di padang ilalang (Adman $d k k$., 2012). Menurut Setyawan (2000), Puspa adalah salah satu jenis tumbuhan dataran tinggi yang dapat tumbuh dengan baik di tempattempat tandus dan kritis, sehingga sesuai untuk upaya penghutanan kembali dan merestorasi hutan pegunungan yang rusak oleh kegiatan pertambangan. Yassir dan Omon (2009), menyatakan bahwa Puspa berpotensi untuk mendukung kegiatan restorasi lahan kritis termasuk lahan pasca tambang.

Oleh karena itu diperlukan kajian anatomi untuk mengetahui kelayakan dan peruntukan kayu tumbuhan ini untuk keperluan manusia (misalnya sebagai bahan furniture, bangunan, kerajinan atau bahan bakar) setelah digunakan revegetasi lahan tambang. Diharapkan kegiatan revegetasi tidak hanya berdampak positif secara ekologis namun juga mempunyai dampak positif untuk ekonomi masyarakat. Sifat anatomi merupakan sifat yang sangat penting untuk diperhatikan dalam menentukan peruntukan dan fungsi kayu, karena struktur anatomi sel-sel penyusun kayu sangat menentukan keberhasilan suatu proses pengolahan yang diterapkan (Wahyudi, 2013).

Pada penelitian ini, akan dilakukan pengamatan dan pengukuran terhadap serat kayu tumbuhan Puspa yang kaitannya adalah untuk mengetahui kelayakan dan peruntukan kayunya. Tumbuhan puspa yang diamati adalah tumbuhan yang sebelumnya dikoleksi di beberapa tempat di Kota Padang. Hasil penelitian ini akan menjadi informasi tentang struktur dan bentuk serat kayu Puspa.

\section{METODE}

Penelitian ini dilakukan dengan metode survei. Pengambilan sampel dilakukan dari 3 lokasi di Sumatera Barat. Sampel yang diambil adalah beberapa potong kayu dari cabang dewasa sepanjang $20 \mathrm{~cm}$ dari individu yang ditemukan di kolasi. Pengamatan ciri anatomi dimensi serat kayu dilakukan dengan membuat preparat maserasi dengan metode Schultze (Priasukmana dan Silitonga 1972), sedangkan untuk pewarnaan dilakukan dengan penambahan safranin mengikuti metode Sass (1958). Data anatomi kayu yang didapatkan dianalisis secara deskriptif dan disajikan dalam tabel, gambar, dan foto.

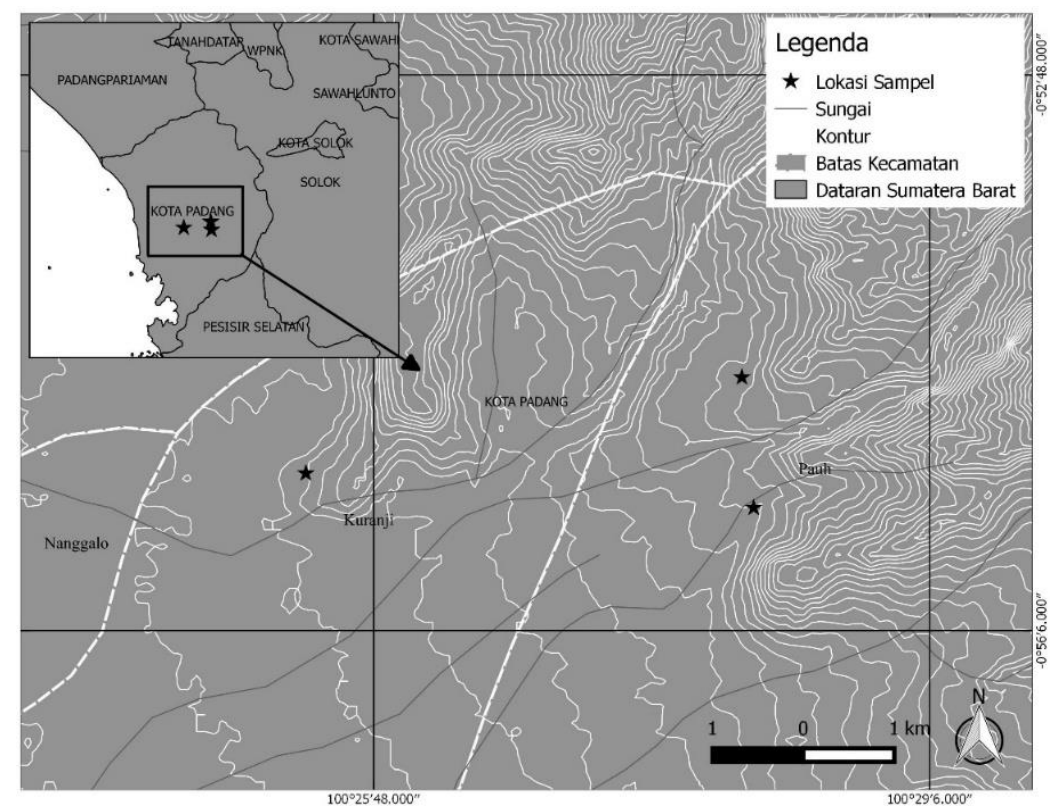

Gambar 1. Peta Pengambilan Sampel Kayu Tumbuhan Puspa (Schima wallichii D.C.)

Sampel yang dikoleksi di lapangan adalah potongan kayu tumbuhan puspa dewasa di beberapa lokasi di Kota Padang. Beberapa parameter anatomi kayu diamati dan diukur di 
laboratorium. Pengamatan anatomi dilakukan dengan pembuatan sayatan pada tiga bidang orientasi (transversal, radial, tangensial) menggunakan mikrotom dengan tebal sayatan antara $12-20 \mu \mathrm{m}$. Selanjutnya sayatan didehidrasi dalam alkohol dengan konsentrasi $50 \%$. Proses dehidrasi dilakukan berturut-turut dengan alkohol 30\%, 20\%, 10\%, lalu dengan akuades. Kemudian sayatan diberi safranin $2 \%$ dan disimpan selama 6-8 jam. Safranin dibuang dan diganti berturut-berturut dengan alkohol konsentrasi 30\%, 50\%, 70\%, 90\%, $100 \%$ dan terakhir dengan xilol. Sayatan dipindahkan ke kaca objek, ditetesi entelan dan ditutup dengan cover glass. Sedangkan untuk pengamatan serat diambil contoh uji berukuran $3 \times 1 \times 10 \mathrm{~mm}^{3}$ kemudian dibuatkan slide maserasi. Contoh uji dimasukkan ke dalam $\mathrm{KOH} 20 \%$ lalu direbus hingga mendidih selama 2-5 menit, selanjutnya dicuci dengan air mengalir selama 15 menit dan setelah itu dimasukkan ke dalam campuran $20 \%$ asam nitrat dengan asam kromat $20 \%$ (1:1) selama 3 jam (sampai bahan menjadi lunak). Contoh uji yang telah lunak dicuci dengan air mengalir selama 20 menit, kemudian didehidrasi dengan seri alkohol $15 \%$ sampai $100 \%$. Pada waktu bahan melewati alkohol $50 \%$ ditambahkan senyawa safranin $1 \%$ ke dalam alkohol. Setelah melewati alkohol $100 \%$, contoh uji dimasukkan ke dalam xilol murni dan diganti sebanyak 2 kali. Bahan yang telah diwarnai diletakkan di atas kaca objek untuk ditetesi dengan canada balsam/entelan, kemudian ditutup dengan kaca penutup (Sass, 1958) dan contoh uji telah menjadi preparat yang siap diamati. Pengamatan dilakukan dibawah mikroskop (Olympus 6071) diukur dimensi dan panjang serat nya. Preparat yang diamati di bawah mikroskop tersebut didokumentasikan dengan menggunakan kamera digital (Canon G10).

Analisis data penelitian ini yang pertama yaitu merata-ratakan setiap pengukuran semua karakter anatomi dan serat tiap sampel kayu Puspa yang dikoleksi di lapangan, kemudian ditabulasi dan dianalisis secara deskriptif. Untuk ciri kuantitatif diamati yaitu panjang serat, diameter dan tebal dinding serat, masingmasing diukur sebanyak 25 kali

\section{HASIL}

Berdasarkan pengamatan yang dilakukan terhadap struktur kayu dari 9 ulangan sampel tumbuhan Puspa di 3 lokasi berbeda, maka didapatkan hasil sebagai berikut:
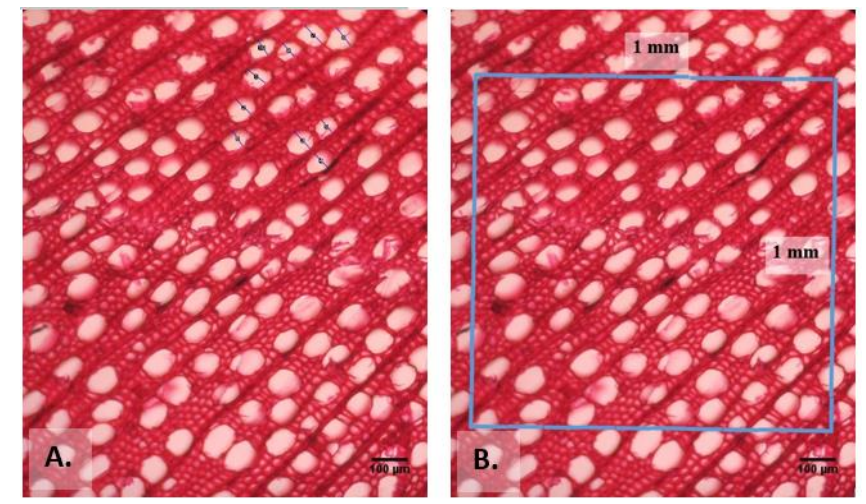

Gambar 2. Foto sayatan tranversal, A. Tipe pori adalah soliter dan bentuk sebaran pori adalah baur; tipe

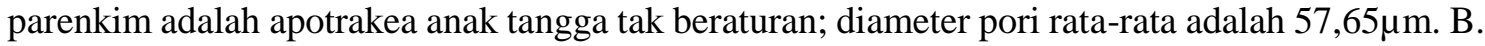
Kerapatan pori rata-rata $>40 \mathrm{buah} / \mathrm{mm}^{2}$ (sangat banyak).

Struktur Anatomi Kayu Pada Sayatan Transversal. 1) Pori. Pada sayatan transversal kayu (Gambar 2) dapat dilihat susunan pori/lingkaran vessel, sebaran pori dan ukurannya. Susunan pori semua individu yang diteliti adalah soliter dengan ukuran ratarata pori yang juga hampir seragam, yaitu termasuk kepada kategori kecil $(50-100 \mu \mathrm{m})$. Lokasi ke-2 merupakan kumpulan individu yang memiliki ukuran diameter pori terkecil dari lokasi lainnya yaitu dengan ukuran ratarata 50,524 $\mu \mathrm{m}$. Individu di lokasi ke-3 adalah individu dengan ukuran pori terbesar $(66,107$ $\mu \mathrm{m})$. Sedangkan untuk pola sebaran pori, 
puspa termasuk kepada kategori baur (tersebar tak beraturan). Sedangkan kerapatan pori ratarata pada tiap lokasi $>40 \mathrm{buah} / \mathrm{mm}^{2}$, artinya termasuk ke dalam kategori sangat banyak. 2) Parenkim. Karakteristik parenkim yang terlihat pada sayatan transversal kayu puspa
(Gambar 2A) dikategorikan apotrakeal baur. Artinya parenkim ini terdiri dari sel-sel tunggal yang tidak berhubungan langsung dengan pembuluh dan tersebar tidak teratur di antara jaringan lain di dalam kayu.

Tabel 1. Struktur Anatomi Schima wallichii (DC.) Korth. (Puspa) di 3 lokasi sampel pada sayatan Transversal

\begin{tabular}{ccccccc}
\hline \multirow{2}{*}{ Lokasi } & \multirow{2}{*}{ Ulangan } & \multicolumn{5}{c}{ Pori/Vessel } \\
\cline { 2 - 7 } & & Kerapatan & Diameter $(\boldsymbol{\mu m})$ & Kategori & Tipe & Sebaran \\
\hline \multirow{3}{*}{1} & 1 & 87.67 & 53.729 & kecil & Soliter & Baur \\
\cline { 2 - 7 } & 2 & 47.18 & 61.44 & kecil & Soliter & Baur \\
\cline { 2 - 7 } & 3 & 104.19 & 53.752 & kecil & Soliter & Baur \\
\cline { 2 - 7 } & rata-rata & $\mathbf{7 9 . 6 8}$ & $\mathbf{5 6 . 3 0 7}$ & Kecil & & \\
\cline { 2 - 7 } 2 & 1 & 83.74 & 47.606 & sangat kecil & Soliter & Baur \\
\cline { 2 - 7 } & 2 & 70.37 & 59.605 & kecil & Soliter & Baur \\
\cline { 2 - 7 } & 3 & 74.3 & 44.363 & sangat kecil & Soliter & Baur \\
\cline { 2 - 7 } & rata-rata & $\mathbf{7 6 . 1 3 6}$ & $\mathbf{5 0 . 5 2 4}$ & Kecil & & \\
\cline { 2 - 7 } 3 & 1 & 112.84 & 55.108 & kecil & Soliter & Baur \\
\cline { 2 - 7 } & 2 & 86.10 & 71.695 & kecil & Soliter & Baur \\
\cline { 2 - 6 } & 3 & 88.07 & 71.519 & kecil & Soliter & Baur \\
\cline { 2 - 7 } & rata-rata & $\mathbf{9 5 . 6 7}$ & $\mathbf{6 6 . 1 0 7}$ & Kecil & & \\
\hline \multicolumn{2}{c}{ rata-rata } & 83.83 & 57.65 & kecil & Soliter & Baur
\end{tabular}

Struktur Anatomi Kayu Pada Sayatan Tangensial. Pada sayatan tangensial kayu (Gambar 3) dapat dilihat susunan jari-jari empelur kayu. Keseluruhan individu tumbuhan Puspa yang diamati memiliki tipe jari-jari empulur kategori uniseriatemultiseriate (Tabel 2). Adapun ukurannya cukup variatif, mulai dari tinggi jari-jari yaitu mempunyai kategori sangat tinggi $(200-400$ $\mu \mathrm{m})$ dan luar biasa tinggi $(>400 \mu \mathrm{m})$. Sedangkan untuk ukuran lebar jari-jari memiliki ukuran dengan kategori lebar $(>1$ $20 \mu \mathrm{m})$ dan luar biasa lebar $(>20)$. Namun kalau dirata-ratakan maka ukuran tinggi jarijari terletak pada kategori sangat tinggi dan lebarnya pada kategori lebar.

Tabel 2. Struktur Anatomi Schima wallichii (DC.) Korth. (Puspa) di 3 lokasi sampel pada sayatan Tangensial

\begin{tabular}{|c|c|c|c|c|c|c|}
\hline \multirow[b]{2}{*}{ Lokasi } & \multirow[b]{2}{*}{ Ulangan } & \multicolumn{5}{|c|}{ Jari-Jari Empulur } \\
\hline & & Susunan jari-jari & $\begin{array}{c}\text { Lebar } \\
(\mu \mathrm{m})\end{array}$ & Kategori & $\begin{array}{l}\text { Tinggi } \\
(\mu \mathrm{m})\end{array}$ & Kategori \\
\hline \multirow{3}{*}{1} & 1 & $\begin{array}{l}\text { uniseriete- } \\
\text { multiseriete }\end{array}$ & 19.587 & lebar & 398.796 & sangat tinggi \\
\hline & 2 & $\begin{array}{l}\text { uniseriete- } \\
\text { multiseriete }\end{array}$ & 21.99 & $\begin{array}{c}\text { Luar biasa } \\
\text { lebar }\end{array}$ & 473.088 & $\begin{array}{c}\text { Luar biasa } \\
\text { tinggi }\end{array}$ \\
\hline & 3 & $\begin{array}{l}\text { uniseriete- } \\
\text { multiseriete }\end{array}$ & 17.736 & lebar & 471.403 & $\begin{array}{c}\text { Luar biasa } \\
\text { tinggi }\end{array}$ \\
\hline \multirow{3}{*}{2} & 1 & $\begin{array}{l}\text { uniseriete- } \\
\text { multiseriete }\end{array}$ & 18.525 & lebar & 334.41 & sangat tinggi \\
\hline & 2 & $\begin{array}{l}\text { uniseriete- } \\
\text { multiseriete }\end{array}$ & 23.801 & $\begin{array}{c}\text { Luar biasa } \\
\text { lebar }\end{array}$ & 353.618 & sangat tinggi \\
\hline & 3 & $\begin{array}{l}\text { uniseriete- } \\
\text { multiseriete }\end{array}$ & 18.647 & lebar & 221.754 & sangat tinggi \\
\hline 3 & 1 & $\begin{array}{l}\text { uniseriete- } \\
\text { multiseriete }\end{array}$ & 18.645 & lebar & 302.966 & sangat tinggi \\
\hline
\end{tabular}




\begin{tabular}{rccccc}
\hline 2 & $\begin{array}{c}\text { uniseriete- } \\
\text { multiseriete }\end{array}$ & 11.161 & lebar & 399.61 & sangat tinggi \\
\hline 3 & $\begin{array}{c}\text { uniseriete- } \\
\text { multiseriete }\end{array}$ & 15.591 & lebar & 342.621 & sangat tinggi \\
\hline rata-rata & & 18.409 & & 366.474 & \\
\hline
\end{tabular}

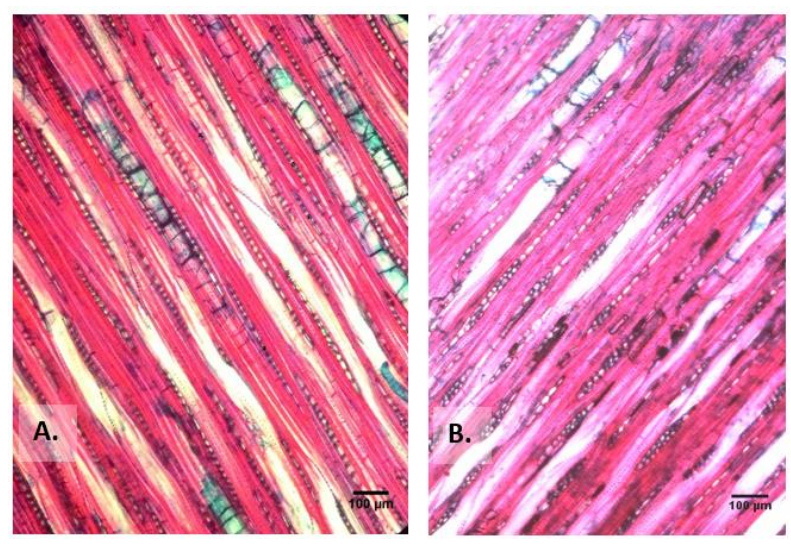

Gambar 3. Foto sayatan tangensial, A. Tipe jari-jari 1 lapis (uniseriate) B. Tipe jari-jari 2-3 lapis sel (multiseriate).

Struktur Anatomi Kayu Pada Sayatan

Radial. Pada sayatan radial kayu (Gambar 4) dapat dilihat komposisi jari-jari empelur kayu. Komposisi jari-jari empelur dari keseluruhan sampel kayu Puspa adalah bertipe heteroseluler yaitu dengan susunan sel baring/ procumbent ray cell dan sel tegak/ upright ray cell. Wheler et al. (1989) menyatakan bahwa komposisi jari-jari empelur terdiri dari dua tipe sel yaitu sel baring dan sel tegak. Sel baring merupakan sel jari-jari empelur dengan dimensi radial yang paling panjang, sedangkan sel tegak merupakan sel jari-jari empelur dengan dimensi aksial yang paling panjang, dimana kedua sel tersebut dapat terlihat pada sayatan radial.

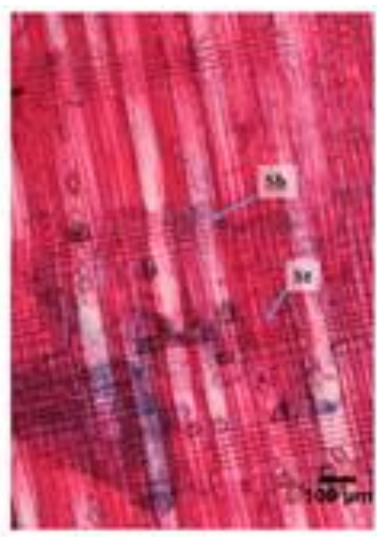

Gambar 4. Foto sayatan radial: tipe komposisi sel penyusun jari-jari empulur adalah heteroseluler (terdiri dari sel tegak dan sel baring). Keterangan: St (Sel tegak), Sb (Sel baring).

\section{Morfologi Serat}

Mandang $d k k$. (2008) menyatakan bahwa serat berdasarkan kategori panjangnya dibedakan menjadi tiga yaitu serat dengan kategori panjang berukuran $(>1600 \mu \mathrm{m})$, serat dengan kategori sedang berukuran (900-1600 $\mu \mathrm{m})$ dan serat dengan kategori pendek berukuran $(<900 \mu \mathrm{m})$. Hasil pengamatan pada Morfologi serat (Gambar 5) menunjukkan tanaman puspa pada lokasi 1, 2 dan 3 berturutturut memiliki panjang serat rata-rata 2016.67 $\mu \mathrm{m}, 1911.67 \mu \mathrm{m}$, dan $1589 \mu \mathrm{m}$. Sehingga serat 
pada semua lokasi tersebut dapat Sedangkan untuk ukuran diameter serat antara dikategorikan berukuran panjang $(>1600 \mu \mathrm{m})$. $11,592-25,371 \mu \mathrm{m}$.

Tabel 3. Karakter serat tumbuhan Schima wallichii (DC.) Korth. (Puspa) di 3 lokasi sampel

\begin{tabular}{|c|c|c|c|c|c|c|}
\hline \multirow{2}{*}{ Lokasi } & \multirow{2}{*}{ Ulangan } & \multicolumn{5}{|c|}{ Serat $(\mu \mathrm{m})$} \\
\hline & & Panjang serat & Kategori & Diameter & Tebal dinding & Tebal lumen \\
\hline \multirow[t]{4}{*}{1} & 1 & 2482 & panjang & 25.371 & 8.202 & 6.07 \\
\hline & 2 & 1685 & panjang & 21.425 & 4.915 & 9.738 \\
\hline & 3 & 1883 & panjang & 21.715 & 7.995 & 4.703 \\
\hline & rata-rata & 2016.67 & & 22.84 & 7.04 & 6.84 \\
\hline \multirow[t]{4}{*}{2} & 1 & 1603 & panjang & 12.617 & 7.848 & 3.567 \\
\hline & 2 & 1558 & Sedang & 11.592 & 3.204 & 3.905 \\
\hline & 3 & 2574 & Panjang & 15.16 & 3.728 & 9.048 \\
\hline & rata-rata & 1911.67 & & 13.12 & 4.93 & 5.51 \\
\hline \multirow[t]{4}{*}{3} & 1 & 1526 & Sedang & 22.744 & 5.29 & 14.123 \\
\hline & 2 & 1395 & Sedang & 18.053 & 5.054 & 10.108 \\
\hline & 3 & 1846 & panjang & 19.053 & 3.857 & 5.766 \\
\hline & rata-rata & 1589 & & 19.95 & 4.73 & 9.999 \\
\hline \multicolumn{2}{|c|}{ rata-rata } & 1839 & panjang & 19 & 6 & 7 \\
\hline
\end{tabular}

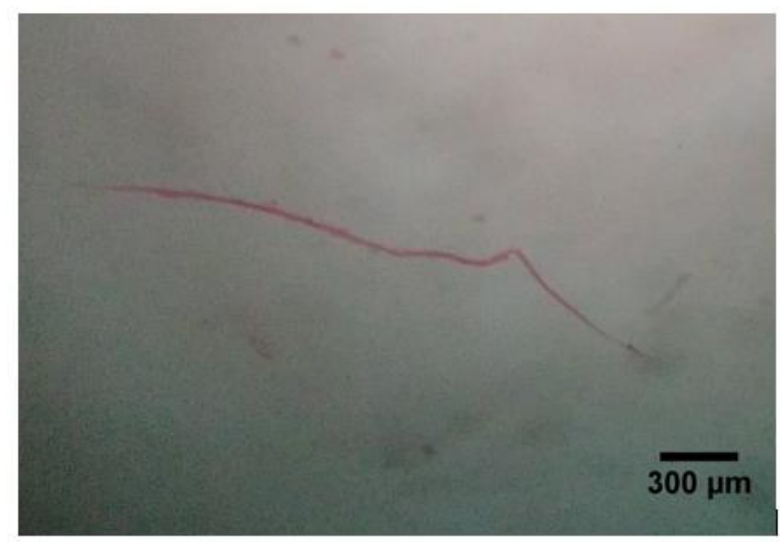

Gambar 5. Foto 1 helaian serat tumbuhan Puspa

\section{PEMBAHASAN}

Pandit dan Kurniawan (2008) melaporkan bahwa pada kayu daun lebar (hardwood) yang mempunyai ukuran diameter lingkaran pori yang sangat kecil $(<50 \mu \mathrm{m})$ akan menyebabkan kayu memiliki kerapatan yang tinggi dan umumnya memiliki kekerasan yang tinggi pula. Di samping itu, kayu yang kerapatannya sangat rendah umumnya kurang mampu memikul beban dan juga kurang efisien dalam proses finishing sehingga permukaan kayu terkesan kurang mengkilap. Untuk itu dapat disimpulkan bahwa kayu puspa ini tergolong cukup keras sehingga dapat digunakan untuk kegunaan konstruksi ataupun sebagai kayu industri karena dengan pori yang sangat kecil dan kerapatan yang sangat tinggi, permukaan kayu dapat mengkilap dengan baik.

Untuk memperoleh corak indah pada jenis-jenis kayu yang mempunyai struktur jarijari multiseriate lebih baik membuat papan radial dibandingkan papan tangensial. Papan radial memiliki penyusutan arah transversal yang lebih kecil dari pada papan tangensial (Mutmainah, 2011). Dengan demikian dalam hal corak, kayu puspa memang belum bisa menyaingi kualitas kayu industri lainnya seperti kayu jati (Tectona grandis) yang telah banyak digunakan (kelas kuat II). Hasil penelitian corak kayu yang unik dan menarik pada jenis kayu jati, menunjukkan bahwa pola pori tata lingkar menyebabkan adanya 
penampilan yang unik dan menarik (Panshin, 1980 dalam Sandri $d k k$., 2013).

Menurut Mandang dan Pandit (2002), parenkima bentuk apotrakeal baur yang dimiliki puspa ini biasanya sukar diamati dengan bantuan lup sehingga sukar digunakan untuk mengidentifikasi jenis kayu di lapangan. Berbeda dengan corak parenkim yang ditampilkan oleh Paraserianthes falcataria (kelas kuat IV-V) yang mana juga disusun oleh sel-sel parenkim apotrakeal namun distribusinya seperti pita-pita tipis memanjang dan teratur ke arah tangensial. Sel-sel parenkim apotrakeal pada kayu sengon ini menghasilkan corak yang terlihat seperti ombak yang bertingkat. Distribusi pita-pita tipis yang teratur menampilkan corak yang teratur dan bertingkat (Mutmainah, 2011). Untuk itu, dari segi parameter bentuk corak parenkim, kayu puspa tidak tergolong cukup bagus.

Penentuan kualitas kayu dilakukan dengan membandingkan karakter anatomi kayu yang diteliti dengan kayu industri yang sudah pernah dilaporkan (Tabel 1). Jenis kayu industri yang dijadikan sebagai pembanding yaitu Diospyros ferrea dan Tectona grandis yang termasuk kelas kuat I dan II (Mandang dan Pandit, 1997), Anthocephalus macrophyllus yang termasuk kelas kuat III dan Paraserianthes falcataria yang termasuk kelas kuat IV-V (Pandit dan Kurniawan 2008).

Susunan pori difus/baur pada kayu $D$. ferrea (kelas kuat I-II) tidak menandakan bahwa kualitasnya berada di bawah kayu $T$. grandis (kelas kuat II), karena susunan pori tata lingkar hanya berpengaruh pada corak/penampilan kayu sehingga terlihat menarik (penyusunan pori mempengaruhi sifat makroskopis yang ditampilkan pada permukaan kayu), dan tidak berpengaruh terhadap tingkat kualitas kayu. Begitu juga dengan sel-sel parenkim apotrakeal yang dimiliki oleh P. falcataria (kelas kuat IV-V) seperti distribusi pita-pita tipis yang teratur menampilkan corak yang teratur dan bertingkat, (Mutmainah, 2011). Selain itu, tipe jari-jari multiseriate hanya memberi keindahan corak pada kayunya (Pandit dan Kurniawan, 2008), namun tidak berpengaruh terhadap tingkatan kualitasnya.

Berdasarkan data pada Tabel 4. dapat dilihat bahwa karakter anatomi yang dimiliki kayu Puspa adalah berpori kecil, jari-jari lebar dan sangat tinggi. Morfologi serat dengan ketebalan dinding termasuk kategori tebal karena lumen atau rongga selnya hampir sebagian terisi dengan lapisan-lapisan dinding. Serat ini berfungsi sebagai penguat batang pohon, oleh karena itu dapat dinyatakan bahwa kayu puspa tergolong kayu yang cukup kuat.

Karakter anatomi yang seperti ini mendekati karakter anatomi kayu D. ferrea dan $T$. grandis sehingga masuk dalam kelas kuat I-II. Dengan demikian kayu puspa ini cocok digunakan untuk tiang dan balok bangunan perumahan dan jembatan, tetapi kurang baik untuk dibuat papan karena mudah berubah bentuk. Selanjutnya jenis kayu ini dapat dipakai untuk lantai, mebel murah, perkapalan (gading-gading, dek) dan bantalan. Hal ini selaras dengan yang dikemukakan oleh Martawijaya (1989), bahwa kayu puspa cukup mudah pengerjaannya, dapat dibubut dan diserut sampai halus serta dapat dipelitur dengan baik. Pengujian sifat pemesinan menunjang keterangan ini, yaitu bahwa kayu diserut, dibor dan dibuat lubang persegi dengan hasil sangat baik serta dapat dibentuk, dibubut dan diamplas dengan hasil baik. Disamping itu Martawijaya juga menyebutkan bahwa kayu ini secara umum termasuk kelas awet III. Daya tahannya terhadap rayap kayu kering termasuk kelas II, sedangkan terhadap jamur pelapuk kayu termasuk kelas III-IV. Berdasarkan percobaan kuburan kayu $S$. wallichii, Hopea ssp. termasuk kelas awet III, sedangkan Schima noronhae termasuk kelas IV. Kemudian Martawijaya juga menambakan bahwa perekatan kayu puspa dengan ureaformaldehida menghasilkan kayu lapis yang memenuhi standar Jerman. 
Tabel 4. Perbandingan beberapa parameter kayu puspa (Schima wallichii (DC.) Korth.) dengan beberapa jenis kayu lainnya yang telah ditentukan kulitas kekuatannya.

\begin{tabular}{|c|c|c|c|c|c|c|c|c|}
\hline \multirow[b]{2}{*}{ No. } & \multirow[b]{2}{*}{ Parameter } & \multicolumn{3}{|c|}{ Jenis kayu yang diteliti } & \multicolumn{4}{|c|}{ Jenis kayu pembanding } \\
\hline & & Puspa Lok.1 & Puspa Lok.2 & Puspa Lok.3 & D. ferrea & T. grandis & $\begin{array}{c}\text { A. } \\
\text { macrophyllus }\end{array}$ & P. falcataria \\
\hline \multirow[t]{4}{*}{1.} & Pori & & & & & & & \\
\hline & $\begin{array}{l}\text { Diameter } \\
(\mu \mathrm{m})\end{array}$ & 56,3 & 50,52 & 66,1 & $50-100$ & 70,5 & $50-100$ & $200-300$ \\
\hline & Sebaran & Soliter & Soliter & Soliter & Soliter & Soliter & Berganda & Soliter \\
\hline & Susunan & Baur & Baur & Baur & Baur & Tata lingkar & Baur & Baur \\
\hline \multirow[t]{3}{*}{2.} & Parenkim & & & & & & & \\
\hline & Sebaran & Baur & Baur & Baur & Scanty & Pita marginal & Baur & Baur \\
\hline & $\begin{array}{l}\text { Hubungan } \\
\text { Dengan } \\
\text { Pori }\end{array}$ & Apotrakeal & Apotrakeal & Apotrakeal & Paratrakeal & Paratrakeal & Paratrakeal & Apotrakeal \\
\hline \multirow[t]{5}{*}{3.} & Jari-jari & & & & & & & \\
\hline & Bentuk & Multiseriate & Multiseriate & Multiseriate & Uniseriate & Multiseriate & Multiseriate & Uniseriate \\
\hline & Komposisi & Heteroselular & Heteroselular & Heteroselular & Heteroselular & Homoselular & Homoselular & Homoselular \\
\hline & $\begin{array}{l}\text { Tinggi } \\
(\mu \mathrm{m})\end{array}$ & 447,7 & 303,3 & 348,4 & $260-1500$ & $500-2000$ & 580 & $150-220$ \\
\hline & $\begin{array}{l}\text { Lebar } \\
(\mu \mathrm{m})\end{array}$ & 19,8 & 20,3 & 15,1 & $100-200$ & $50-100$ & 44 & $15-30$ \\
\hline \multirow[t]{5}{*}{4.} & Dimensi Ser & & & & & & & \\
\hline & $\begin{array}{l}\text { Panjang } \\
(\mu \mathrm{m})\end{array}$ & 2017 & 1912 & 1589 & 1193 & 1316 & 1979 & 1070 \\
\hline & $\begin{array}{l}\text { Diameter } \\
(\mu \mathrm{m})\end{array}$ & 22,8 & 13,1 & 19,9 & 42,2 & 23,1 & 54 & 25,5 \\
\hline & $\begin{array}{l}\text { Tebal } \\
\text { Dinding } \\
(\mu \mathrm{m})\end{array}$ & 7 & 4,9 & 4,7 & 3,3 & 3,2 & 3,2 & 3,0 \\
\hline & $\begin{array}{l}\text { Diameter } \\
\text { Lumen } \\
(\mu \mathrm{m})\end{array}$ & 6,8 & 5,5 & 9,9 & 32 & 18,2 & 47,6 & 19,5 \\
\hline 5. & Kelas Kuat & I-II & I-II & I-II & I & II & III & IV-V \\
\hline
\end{tabular}

\section{KESIMPULAN}

Adapun kesimpulan dari penelitian ini yaitu penelitian yang dilakukan di ke-3 lokasi tidak memperlihatkan nilai rata-rata yang begitu berbeda jika diamati berdasarkan karakter anatomi. Berdasarkan karakter anatominya tersebut, tumbuhan puspa $(S$. wallichii) menunjukkan beberapa profil, pertama mempuyai pori dengan kategori kecil dan sangat kecil dengan tipe soliter dan pola sebaran yaitu baur serta memiliki tipe parenkim apotrakeal baur. Kedua, jari-jari empulur berbentuk uniseriate-multiseriate, tingginya tergolong kedalam kategori sangat tinggi sedangkan lebarnya tergolong kedalam kategori lebar. Ketiga, komposisi jari-jari empulur bertipe heteroseluler yaitu dengan susunan sel baring/ procumbent ray cell dan sel tegak/ upright ray cell. Keempat, panjang serat termasuk kedalam kategori sedang - panjang dengan dinding serat yang tebal dan lumen yang sempit. Penentuan kualitas kayu yang dilakukan dengan membandingkan karakter anatomi kayu yang diteliti dengan kayu industri yang sudah pernah dilaporkan, menunjukkan bahwa tumbuhan puspa $(S$. wallichii) masuk ke dalam kelompok kayu kuat kelas I-II. Data penelitian ini dapat digunakan sebagai bahan acuan rekomendasi penggunaan tumbuhan jenis puspa untuk dijadikan sebagai kandidat tanaman reklamasi di lahan pascatambang.

\section{DAFTAR PUSTAKA}

Adman, B, Hendarto B, Sasongko DP. 2012. Pemanfaatan Jenis Pohon Lokal Cepat Tumbuh Untuk Pemulihan Lahan Pascatambang Batubara (Studi Kasus Di PT. Singlurus Pratama, Kalimantan Timur). Jurnal Ilmu Lingkungan. vol 10 (1): https://doi.org/10.14710/jil.10.1.19-25.

Afifah N. 2014. Pertumbuhan Beberapa Jenis Bibit Pohon Hutan yang Diinokulasi Endomikoriza Dari HPPB UNAND Pada Tanah Lahan Bekas Tambang PT. Semen Padang. [Skripsi]. Padang: Jurusan Biologi. Universitas Andalas. 
Ashraf MA, Maah MJ, Yusoff I. 2011. Heavy metals accumulation in plants growing in ex tin mining catchment. Int. J. Environ. Sci. Tech. vol 8 (2): 401-416. https://doi.org/10.1007/BF03326227.

Mandang YI dan Pandit IKN. 1997. Pedoman Identifikasi Kayu di Lapangan. Bogor: Prosea, Pusat Diklat Pegawai dan SDM Kehutanan.

Mandang YI dan Pandit IKN. 2002. Pedoman Identifikasi Kayu di Lapangan. Bogor: Yayasan PROSEA Indonesia

Mandang YI, Ratih D, Tajudin EK, Siti N. 2008. Pedoman Identifikasi Kayu Ramin dan Kayu Mirip Ramin. Bogor: Departemen Kehutanan Badan Penelitian Dan Pengembangan Kehutanan Bekerja Sama Dengan International Tropical Timber Organization.

Martawijaya A. 1989. Atlas Kayu Indonesia: Jilid II. Bogor: Pusat Penelitian dan Pengembangan Hasil Hutan.

Menteri Kehutanan Republik Indonesia. 2008. Peraturan Menteri Kehutanan Nomor P. 61/menhut-ii/2008 tentang Ketentuan dan Tata Cara Pemberian Izin Usaha Pemanfaatan Hasil Hutan Kayu Restorasi Ekosistem Dalam Hutan Alam Pada Hutan Produksi Melalui Permohonan. Berita Negara Republik Indonesia Tahun 2008 No.68. Biro Hukum dan Organisasi. Jakarta.

Mutmainah U. 2011. Corak Beberapa Jenis Kayu Perdagangan Indonesia. [Skripsi]. Bogor: Fakultas Kehutanan, Institut Pertanian Bogor.
Pandit IKN dan Kurniawan D. 2008. Anatomi Kayu: Struktur Kayu, Kayu Sebagai Bahan Baku dan Ciri Diagnostik Kayu Perdagangan Indonesia. Bogor: Centium.

Priasukmana S dan Silitonga. 1972. Cara Pengukuran Serat Kayu. Bogor: Lembaga Penelitian Hasil Hutan LPHH, Direktorat Jenderal Kehutanan, Departemen Pertanian Bogor.

Sandri Y, Maideliza T, Syamsuardi. 2013. Struktur Anatomi Kayu Beberapa Jenis Buah-Buahan. J. Bio. UA. 2(3): 181-187

Sass JE. 1958. Botanical Microtechnique. $3^{\text {rd }}$ Ed. IAWA: Iowa State College Press. University of Michigan.

Setyawan AD. 2000. Tumbuhan Epifit pada Tegakan Pohon Schima wallichii (D.C.) Korth. di Gunung Lawu. Jurnal Biodiversitas. 1(1):14-20.

Wheler EA, Baas P, Gasson E. 1989. IAWA List of Microscopic Features for Hardwood Identification. IAWA Bulletin. N.s. vol. 10 (3): 219-332.

Yassir I dan Omon RM. 2009. Pemilihan Jenis-Jenis Pohon Potensial Untuk Mendukung Kegiatan Restorasi Lahan Tambang Melalui Pendekatan Ekologis. Prosiding Workshop IPTEK Penyelamatan Hutan Melalui Rehabilitasi Lahan Pascatambang Batubara. Balai Besar Penelitian Dipterokarpa. Samarinda. hal: 64-76.

Wahyudi I. 2013. Hubungan Struktur Anatomi Kayu Dengan Sifat Kayu, Kegunaan Dan Pengolahannya. Bogor: Diskusi LitBang Anatomi Kayu Indonesia. 